\title{
Immigration Policy and Justice in the Era of COVID-19
}

Holly Ventura Miller ${ }^{1}$ - Melissa Ripepi ${ }^{2}$ - Amy M. Ernstes ${ }^{2}$ - Anthony A. Peguero ${ }^{2}$

Received: 3 June 2020 / Accepted: 8 June 2020 /

Published online: 11 June 2020

(C) Southern Criminal Justice Association 2020

\begin{abstract}
The U.S. immigration system has not escaped the challenges presented by the COVID19 pandemic. Concerns have been raised about policy changes, enforcement actions, immigrant detention, and deportation practices during the outbreak. In response, dozens of lawsuits have been brought against the government on behalf of undocumented immigrants and detainees, ranging from the conditions of ICE detention facilities to the public charge rule. While most cases continue to move through the federal court system, a number of district court judges have already ruled in favor of the plaintiffs. This paper focuses on three particular areas of immigration policy and practice during COVID: ICE enforcement actions, immigrant detention, and deportations. We summarize the current state of extant data and evidence on each of these and examine questions that remain for further research.
\end{abstract}

Keywords Immigration · COVID-19 · Immigrant detention · Immigration and Customs Enforcement (ICE)

Holly Ventura Miller

holly.miller@unf.edu

Melissa Ripepi

mblythe@vt.edu

Amy M. Ernstes

ernstes@vt.edu

Anthony A. Peguero

anthony.peguero@vt.edu

1 Department of Criminology \& Criminal Justice, University of North Florida, Jacksonville,

FL, USA

2 Department of Sociology, Laboratory for the Study of Youth Inequality and Justice, Virginia Tech, Blacksburg, VA, USA 


\section{Introduction}

The novel coronavirus, COVID-19, was first detected in Wuhan, China in late 2019 and within months had upended much of the normative activities of daily economic, social, and governmental life. The criminal justice system was not spared as virtually all aspects of the American legal system were faced with increased logistical and public health concerns overnight. The strain on criminal justice was felt perhaps nowhere as acutely as in New York City, the epicenter of the outbreak, where the NYPD to date (May 25, 2020) has lost 43 officers with another 5793 testing positive for COVID-19. Police and correctional officers have become front-line workers during the pandemic with heightened exposure to high-risk situations and locations, often lacking the requisite personal protective equipment (PPE) necessary to reduce potential exposure. Contact with the public combined with the health dangers posed by correctional and detention facilities generally have placed these workers squarely in the midst of a system-wide crisis. In a May 2020 survey of 32 state health departments, the CDC reports that at least 4893 inmates and 2778 staff have been diagnosed with COVID-19, while 88 and 15, respectively, have been lost to the virus across 420 separate prisons and jails (CDC 2020). The numbers are almost certainly higher.

The immigration system similarly has been impacted by COVID-19; this is especially true given the criminalization of immigration processes more generally in recent years. Nowhere is this more so the case than in immigrant detention policies and practices. Immigrant detention, a practice rarely utilized during most of the twentieth century, has increased since the 1980s and reached its peak during the Trump administration. Tens of thousands of immigrants are currently being held in detention facilities and local jails on any given day, far exceeding the number of beds reported by the Department of Homeland Security (DHS). These conditions are ripe for spread of communicable diseases, and indeed, early reports indicate that these detention facilities may be hidden COVID-19 hotspots.

Legal activity related to immigration policy and practice, if anything, has increased during the pandemic, with lawsuits being filed by detainees, staff, and legal organizations on behalf of immigrants. The ACLU alone has filed 90 legal actions regarding COVID-19, including state and city chapters that have filed lawsuits against U.S. Immigration and Customs Enforcement (ICE) detention centers and processing centers in California, Maryland, Massachusetts, Michigan, Ohio, Pennsylvania, Texas, and Washington (ACLU 2020a, 2020b). As early as March 2020, a federal court in Harrisburg, PA ruled that ICE must release 10 individuals who had sued on the basis of being at high risk of contracting coronavirus (ACLU-PA, 2020); similar decisions were handed down in New Jersey and Massachusetts. In April 2020, a federal judge in California ordered an ICE detention facility to release detainees and facilitate social distancing (Kopetman 2020), a ruling followed by a federal judge in Miami who ordered three ICE facilities in South Florida to release detainees due to the pandemic (Madan 2020a). Most recently, another federal judge ordered the government to better explain why it had yet to release more than 350 parents and children from three family detention centers (Merchant 2020).

On March 15, a coalition of immigration system functionaries including judges, attorneys, and ICE officers sent a letter to the U.S. Department of Justice requesting an emergency closure of the nation's immigration courts (Brennan Center, 2020). 
Subsequently, a lawsuit was brought to suspend in-person immigration court processing during the outbreak, a petition denied by a federal judge in Washington, DC (Kruzel 2020). The judge ruled that since the immigration system writ large had already modified its practices and protocols in light of COVID-19, no sweeping stoppage of cases was warranted.

The coronavirus outbreak has also provided the Trump administration with a pretext for alterations to existing immigration policies. Early on in the outbreak, DHS moved to close the southern border, immediately removing any migrants encountered by CBP by sending them back to Mexico or Central America within about two hours. Those from other nations are transferred to ICE for rapid deportation, including those potentially seeking asylum and children (Associated Press 2020). This order was first issued in March and has since been renewed in April and May, the latter of which notably had no end date. On May 19, 2020, the DOJ asked the 9th Circuit Court of Appeals to "replace" the Flores agreement, which would allow the administration to modify the rules governing the detention of migrant children and families in DHS facilities. Though this too was predicated on stopping the spread of the coronavirus, the administration announced as early as 2019 its desire to modify the court settlement; Flores was what also was used to justify family separation policies in 2018 (Stracqualursi et al. 2019). Due to the public health and economic threat posed by the virus, the administration has also suspended immigration to the U.S. for at least 60 days beginning in April to limit competition for jobs (Associated Press 2020).

The legal issues discussed above are myriad and dynamic, impacting various aspects of the immigration system, from lawful immigration to asylum seekers and refugees to unaccompanied children and detention center conditions. While each of these deserve full empirical attention, this paper focuses on three particular areas of immigration policy and practice during COVID: ICE enforcement actions, immigrant detention, and deportations. We summarize the current state of extant data and evidence on each of these and examine questions that remain for further research.

\section{Are ICE Enforcement Actions Continuing during COVID-19?}

On March 18th, 2020, ICE announced that it would cease enforcement actions during COVID-19, except for individuals who have committed crimes or pose a threat to public safety in an effort to decrease the spread of the virus and to encourage those who need medical attention to seek it. Specifically, ICE stated that "...During the COVID19 crisis, ICE will not carry out enforcement operations at or near health care facilities, such as hospitals, doctors' offices, accredited health clinics, and emergent or urgent care facilities, except in the most extraordinary of circumstances...Individuals should not avoid seeking medical care because they fear civil immigration enforcement" (ICE, 2020). ICE also temporarily suspended in-person reporting requirements as well as home visitations. Despite this announcement, ICE conducted immigration raids in states such as California even after the governor had declared a state of emergency and issued a stay at home order (Los Angeles Times, 2020). Though it did make fewer arrests in April compared to March, ICE still conducted operations leading to the arrest of at least 80 people in the Los Angeles area alone (Perrett 2020). 
Other ICE enforcement actions since the start of the coronavirus pandemic have taken place as well, including an arrest of an 18-year-old on his birthday residing in an Office of Refugee Resettlement shelter in Westchester, NY (Sidahmed 2020). This individual was then transferred to immigrant detention at a nearby county correctional facility at the height of New York's coronavirus surge. Residents in San Diego and Riverside Counties in southern California report increased border patrol checkpoints along I-15, a major throughway running north through the state from the Mexican border, as well as checkpoints along state roads. Increased use of "roving patrols" and at least four arrests since March 23 have also been reported to the media (Srikrishnan 2020).

In the weeks prior to the March 18th announcement, reports surfaced that immigrants were being targeted at hospitals, courthouses, and their children's school (Burness and Hindi 2020; Lanard 2020). The Miami Herald reported that new arrests continued throughout the end of March including for those with non-criminal offenses (Madan 2020b). These arrests were particularly notable as these individuals were then detained in several South Florida detention facilities which have since become plagued with coronavirus. These facilities have also been the target of legal action and ordered by the federal courts to release detainees due to unsafe conditions (Madan 2020a).

Though ICE pledged to limit enforcement actions during the pandemic, the current situation in its detention facilities are significantly impacted by the administration's immigration crackdown in early 2020 when New York, for example, saw initial court appearances double in February and March compared to the December and January. In the weeks prior to the March 18th announcement, ICE ramped up enforcement actions, including a March 6 raid in New Rochelle, NY, just hours before the area being designated a "containment zone" by Governor Andrew Cuomo (Devereaux 2020). Major ICE operations were also carried out in Michigan and Ohio in early February, well after coronavirus had gotten a foothold in the U.S. (Warikoo 2020).

\section{Are U.S. Immigration Dentition Centers a Shrouded Hotspot for COVID-19?}

Prior to COVID -19, a growing body of evidence was accumulating that immigrants are exposed to dangerously poor health conditions and services within ICE detention centers. Immigrant adults and children in detention centers experience detrimental physical and mental health outcomes, as do family units and households outside the immigration detention centers (Long 2018; Ornelas et al. 2020). For example, detained immigrants have increased levels of musculoskeletal, gastrointestinal, respiratory, and neurologic symptoms while being detained and also commonly experienced anxiety, depression, posttraumatic stress disorder, difficulty with relationships, and self-harming behavior. Immigration detention itself undermines family authority and ability to respond to their children's needs; this difficulty is complicated by parental mental health problems. In more extreme cases, immigrants' mortality and death have been associated with being detained (Long 2018; Ornelas et al. 2020).

A 2018 report titled "Code Red: The Fatal Consequences of Dangerously Substandard Medical Care in Immigration Detention" reviewed fifteen deaths that occurred in ICE detention between December 2015 and April 2017 (Long 2018). With the help of medical experts, the report concludes that in more than half of those cases, substandard 
medical care including unreasonable delays, botched emergency responses, and poor practitioner care contributed to the deaths. Many have argued that because immigration detention centers are private, the lack of transparent policy health procedures and practices contribute to poor health conditions and services common in these detention centers (Ackerman and Furman 2013; Hernández et al. 2018). Others suggest that poor health conditions and services are common in immigration detention centers because of the social, political, and cultural construction as undocumented or "illegal" immigrants are inherently "criminal" who do not warrant public healthcare, attention, and care (Ackerman and Furman 2013; Miller and Peguero 2018; Zarrugh 2020). This leads us to our question for this section: are immigration dentition centers a shrouded hotspot for COVID-19?

Although the situation changes on a daily basis, ongoing reports indicate that this system of inadequate medical access care and resulting poor health conditions and outcomes has only been exacerbated by COVID-19. Because the demand for medical needs are greater for everyone generally, the gap between need and supply has only become more apparent in detention centers. It is especially dire for people in such facilities, given that exposure to the virus can lead to relatively quick and lifethreatening consequences. Like many facilities tasked with providing medical care, these detention facilities must now concern themselves with need for COVID tests, personal protective equipment like gloves and masks, and increased access to medical treatments such as oxygen and ventilators.

Due to the highly contagious nature of COVID-19, the crowded conditions of detention centers exacerbates the situation, placing those held in these facilities at greater risk for contracting and spreading the virus. This is true for those who are detained, as well as employees at these facilities. As of this article's writing, ICE's website reports that: as of May 11, 2020, there are 29,675 people being detained, with 869 confirmed COVID-19 cases, with 1686 having been tested. The website states that 42 ICE employees working at detention centers have confirmed cases. Numbers are updated on ICE's website under the tab, "confirmed cases" (https://www.ice. gov/coronavirus).

The heightened risk at detention centers can be evaluated in more concrete terms against CDC guidelines. In short, detention centers cannot meet those basic, general guidelines. Social distancing of an ideal six feet is impossible to implement within detention centers given the spatial and physical limitations. This inability also means that if someone at a detention center (an employee or a detainee) contracts the virus, the likelihood of spread is increased, along with the potential speed and magnitude of spread. The danger of the situation is intensified in that many people may be asymptomatic carriers and spread the virus without knowing (Johns Hopkins University 2020); in cramped quarters, by the time symptoms start to show, many may have already been infected. Additionally, people who are detained have limited ability to use disease prevention measures like hand-washing, both due to access and supplies; it is harder to practice medical isolation, which the CDC defines as: "confining a confirmed or suspected COVID-19 case (ideally to a single cell with solid walls and a solid door that closes), to prevent contact with others and to reduce the risk of transmission" (NCIRD, 2020); and it is more difficult to institute a quarantine, which the CDC defines as "the practice of confining individuals who have had close contact with a COVID-19 case to determine whether they develop symptoms of the disease" (NCIRD, 2020). 
Acknowledging that facilities like jails, prisons, and detention centers possess significant impediments to these recommendations, the CDC has produced the article, "Interim Guidance on Management of Coronavirus Disease 2019 (COVID-19) in Correctional and Detention Facilities" (NCIRD, 2020). In it, guidance for correctional and detention facilities is organized into three sections: (1) operational preparedness, which aims to prepare a facility for the situation of transmission of COVID-19 into the facility, (2) prevention, which concerns preventing the spread from outside to inside of the facility, and (3) management of COVID-19, which describes how to manage confirmed and suspected cases.

Yet still, numerous reports, internal strikes, and resulting lawsuits indicate that many facilities fail to meet these guidelines. Per the Lancet, "ICE facilities do not have the staffing capacity or facilities to screen, quarantine to monitor for symptoms, isolate infected individuals, or deliver medical management in a setting with high rate of infection" (Meyer et al. 2020). Other reports have found a lack of needed supplies and PPE such as cleaning supplies, masks, gloves (Trevizo 2020), and some have noted that detainees are not being given PPE nor are they being tested, even when they are sick and showing symptoms of COVID-19 (Lippa 2020). Detainees have reported that "access to soap, hand sanitizer, and disinfecting equipment is very limited or nonexistent" (Montoya-Galvez 2020d).

As a result of these conditions, detainees at facilities across the country have organized related strikes and protests. Some examples include hunger strikes that have been organized across California, including a 200 person strike at Otay Mesa Detention Center in San Diego (where, at the time, 120 detainees had confirmed cases) (Plevin 2020) and a strike at Adelanto ICE Processing Center prompted by staff's failure to provide detainees PPE including masks, gloves, and cleaning supplies (Castillo 2020). Protests have also been organized in detention centers in Louisiana (Montoya-Galvez 2020d), and at least five hunger strikes have taken place at an ICE processing center in Pearsall, Texas alone - some because detainees are asking for information (as detainees have reported being given false information about numbers and not being told about who has the virus), and some for greater testing after positive cases (Trevizo 2020).

Since the spatial parameters of detention centers precludes the CDC guidelines of medical isolation and quarantining, many are instead using a practice of cohorting, which refers to isolating cases in groups and quarantining groups of people together who have possibly been exposed. While the CDC outlines this practice in its guidelines for detention centers, it is intended as a last resort. One federal lawsuit has already been filed which "alleges immigration officials are violating CDC guidelines by using cohorting instead of releasing immigrant detainees where possible" (Joffe-Block and Fernández 2020a). Since immigration detention is a civil, and not criminal matter, "ICE has the broad authority to release its detainees, including by placing them in programs in which officials monitor them through ankle bracelets or check-ins" (MontoyaGalvez 2020f), and many similar lawsuits have been filed pushing for releases.

As of May 15, 2020, the ACLU website states that it has filed 90 legal actions regarding COVID-19 (www.aclu.org). These include state and city chapters that have filed lawsuits against ICE detention centers and processing centers in California, Maryland, Massachusetts, Michigan, Ohio, Pennsylvania, Texas, and Washington (American Civil Liberties Union 2020a; American Civil Liberties Union 2020b; ACLU Massachusetts 2020; ACLU Pennsylvania 2020; Carmody 2020; Coleman 
2020; Hancock 2020; Morrissey 2020.) An ongoing list of other organizations also filing lawsuits includes the University of Miami School of Law's immigration clinic, the Southern Poverty Law Center, Rapid Defense Network, Legal Aid Service of Broward County, and the law firm of Prada Urizar, PLLC (SPLC, 2020). Many of these lawsuits are seeking the release of detainees, some with focus on high risk groups. Other groups, like the New York Lawyers for Public Interest (NYLPI), have published reports documenting the poor conditions of detention centers and the increased urgency of these conditions in this era of COVID-19. The NYLPI report, "Still Detained and Denied," found "serious, often life-threatening deficiencies in the medical care provided to New Yorkers in area immigration detention centers" (NYLPI, 2020). Federal judges in some states have allowed for the release of small numbers of detainees who are at high risk for contracting the virus, but many advocacy groups and lawmakers say it is not enough to address the dangerous conditions in which detainees are being forced to exist (Montoya-Galvez 2020c). At the end April, a group of 26 senators signed a letter calling on the Department of Homeland Security to investigate ICE detention facilities to assess whether they have adopted necessary guidelines in regard to COVID-19 (U.S. Sentator D. Feinstein, 2020).

Reports suggest a lack of transparency when it comes to number of confirmed cases. Some inaccuracy comes from the testing rate; only about $5 \%$ of the population of people detained have been tested (Trevizo 2020). Some reports note ICE's initial unwillingness to share numbers about cases and that it took lawsuits to prompt ICE to share this information (SPLC, 2020). Other reports highlight instances in which ICE has released information that is later contradicted, thus leading to questions about the accuracy of information provided (Joffe-Block and Fernández 2020b). Lack of transparency is a similar issue for employee cases. While ICE reports numbers of confirmed cases among its employees at detention centers, this does not include the many other employees at these facilities who are not directly employed by ICE (those who work for the county, or private health care companies, etc.) (Gomez et al. 2020).

Detainees are also facing greater impediments to having their concerns heard and their experiences during the pandemic shared. Some detention centers are requiring lawyers to bring their own PPE to meet detainees (Gomez et al. 2020), and many facilities do not have teleconferencing that allows for confidentiality due to unsecure connections or having to have conversations in earshot of employees (Gomez et al. 2020). Reports have also been surfacing about liability waivers: detainees being required to sign liability waivers in exchange for PPE (Democracy Now! 2020; Proctor 2020; Rivlin-Nadler 2020) and detainees "being coerced into signing a paperwork that provides a positive evaluation of conditions in the detention center" (Acevedo 2020). ICE has also been minimizing and in cases outright denying some of the aforementioned strikes and protests in detention centers, despite reports and evidence otherwise (Brown 2020; Castillo 2020).

\section{Are U.S. Immigration Policies and Court Decisions Spreading and Deporting COVID-19?}

Beginning in the 1980s, immigration law reforms merged practices from criminal law and justice with immigration law and enforcement, the cumulative effect of which was 
to create a murky area in which immigration policing practices and court processes are not regulated by the constitutional protections afforded to individuals within the criminal justice system (García Hernández 2013); namely the 4th (search and seizure), 5th (due process), and 6th (right to counsel) amendments. Individuals within 100 miles of U.S. international borders may be subjected to warrantless searches (Chacón 2010). Noncitizens can legally be deported without judicial review (Menjívar et al. 2018.). Though immigrants appearing in immigration court technically have a right to counsel, the immigration courts are in no way obligated to provide them with counsel if they do not provide their own; most are unable (Eagly and Shafer 2015).

This trend towards the tightening of immigration allowances while limiting protections increased under the Obama administration as was evidenced through an upsurge in detention and deportation (Miller and Peguero 2018; Ricciardelli et al. 2019). Yet, under the Trump administration the rate of detentions and deportations has escalated to unprecedented levels. Policies enacted in the past three years that have contributed to this increase include: promotion of a U.S. Southern border wall; implementation of Zero-Tolerance which ordered the separation of children from their families and their subsequent detainment without a clear means to facilitate reunion; deployment of 5000 U.S. soldiers to the Southern border and sanctioned use of teargas on children and families trying to cross; and industrial tent facilities that housed over 3000 separated children adolescents without due process (Hernández et al. 2018; Van Hook and Glick 2020; Zarrugh 2020). It is important to note these policies and lack of protections for context as we move into our final considerations: First, how immigration policies both prior to COVID-19 and under its guise are accelerating the U.S. towards a near total dismantling of protections for immigrant men, women, children, and families. Second, through implementation of these policies, is the U.S. government spreading and deporting Covid-19?

Since March 21, 2020, the southern border of the United States has been, in effect, sealed. The day before, the Centers for Disease Control and Prevention (CDC) had "issued a largely unnoticed but sweeping order authorizing the summary expulsion of noncitizens arriving at the border without valid documents" (Guttentag 2020). By application of a medical quarantine authorization, the order supersedes "the protections of the immigration and refugee laws through the use of an unreviewable Border Patrol health 'expulsion' mechanism unrelated to any finding of disease or contagion" (Guttentag 2020). In the six weeks between the order and the beginning of May, the U.S. expelled over 20,000 migrants (Montoya-Galvez 2020a) through either deportation to their country of citizenship or, for cross-border migrants, by processing and then returning them to Mexico or Canada (Montoya-Galvez 2020b); a process that takes, on average, 96 min (Hernández and Miroff 2020). Access to U.S. immigration courts is denied as is the opportunity to file a claim for humanitarian protection (MontoyaGalvez 2020a). Individuals seeking refuge through asylum and unaccompanied children, groups that are normally protected by both U.S. and international law, have been pointedly targeted in the enforcement of this measure.

Between 2016 and 2018 the U.S. government initiated two immigration policies that were designed to function as barriers specifically to migrants seeking asylum: metering and the Migrant Protection Protocols (MPP). According to the Immigration and Nationality Act (INA), "Any alien who is physically present in the United States or who arrives in the United States (whether or not at a designated port of arrival and including an alien who 
is brought to the United States after having been interdicted in international or United States waters), irrespective of such alien's status, may apply for asylum" (Immigration and Nationality Act 1952). The practice of metering, contrary to the INA, works by requiring all requests for asylum to cross the border at a port of entry, and then limiting the number of people who are able to access asylum at each port of entry (Frederick 2019; American Immigration Council 2020a). Guards at these border crossings direct individuals who are barred from the process to a point-person on the Mexican side of the border where his or her name is placed on a waiting list, the backlog of which can require days or months of waiting in Mexico with daily check-ins regarding an individual's list status (Lu and Watkins 2019). Under MPP, or the "Remain in Mexico" program, if access to make a claim of asylum is granted, the individual is given notice to appear in immigration court and then, as the program title suggests, returned to Mexico to await the court date (American Immigration Council 2020a).

In 2019, over 60,000 people were returned to Mexico under MPP (Miroff 2020). As a result, improvised camps have sprung up along the border in Mexico outside of ports of entry; camps that are lacking in basic sanitation, reliable access to medical services, food or water sources, and security (Glass et al. 2019). The United Nations High Commissioner for Refugees (UNHCR) has issued a statement that they are prepared to fold them under their protection and management as refugee camps (Van Fossen 2020), and yet the U.S. and Mexico have both been unwilling to declare the situation on the border officially "an emergency", the mechanism required for the UNHCR to take over (Van Fossen 2020). UNHCR refugee status would allow for three broad protections: 1) basic needs in the form of shelter and security; 2) the implementation of infrastructure necessary to support large-scale health initiatives; and 3) access to a lawyer (Van Fossen 2020). Mexico's stated reasoning for denying the UNHCR is they do not want permanent settlements (Glass et al. 2019). The United States' logic is less well-defined, unless juxtaposed next to the goal of ending asylum along the southern border. According to Elora Mukherjee, Professor of Law and Director of the Immigrants' Rights Clinic at Columbia Law School, "given the complexity of immigration law and language and cultural barriers, the process of seeking asylum when someone is in the United States is hard enough. Requiring asylum seekers to remain in Mexico makes navigating the process virtually impossible" as it severely limits migrant's access to legal counsel (Mukherjee 2020). Only 4\% of those who "remain in Mexico" under MPP have been able to access a lawyer (Mukherjee 2020). In 2018, the year before MPP was enacted, the U.S. granted asylum to 13,248 people (Miroff 2020). As of December of 2019, one year after MPP began, 29,309 cases had been processed, and 187 people were granted asylum (Mukherjee 2020).

Until the public health order of March 20th 2020, one group that was exempt from the asylum processes discussed above was that of unaccompanied minors, defined by U.S. law to be a child who is under the age of 18 , has no lawful immigration status, and either does not have a parent or legal guardian in the United States or that parent/legal guardian is unable to care for them (Homeland Security Act of 2002). Resulting from the U.S. Supreme Court decision Reno v Flores, the Flores Agreement set standards of legal protections for unaccompanied minors in the custody of U.S. immigration agencies ( Wu 2018). These standards were codified by the William Wilberforce Trafficking Victims Protection Reauthorization Acts of 2000 (TVPRA, reauthorized in 2003, 2005, 2008, and 2013). Under TVPRA, unaccompanied minors from non- 
contiguous countries must be transferred from CBP/ICE custody to Health and Human Services (HHS) Office of Refugee Resettlement (ORR) within three days (MontoyaGalvez 2020b). ORR is mandated to keep the minors in the "least restrictive setting" until they can be released to either family members or approved sponsors while they wait for their immigration court proceedings (Cheatham 2020). Under TVPRA, DHS is mandated "'to the greatest extent practicable' that unaccompanied children in HHS custody have counsel. .. not only "to represent them in legal proceedings," but to "protect them from mistreatment, exploitation, and trafficking" (American Immigration Council 2020b). In March of 2020, ORR received 1852 from CBP custody. In April, that number fell to just 58 (Montoya-Galvez 2020g). Understanding the scope of this issue is challenging due to the same transparency issues discussed previously in the section on detention under COVID-19. The number of children, specifically unaccompanied minors, who have been 'expelled' under CDC order is not reported by the DHS, though multiple news sources have put that number, for the month of April, between 400 and 700 children (Montoya-Galvez 2020a; Guttentag and Bertozzi 2020), though immigration officials in Guatemala have reported receiving 417 minors alone from U.S. custody since March (O'Toole and Carcamo 2020a).

Now, under the COVID-19 public health order, the asylum system is, in effect, shut down for both accompanied minors and adults. The MPP courts have been closed through June 19, 2020, though that date could easily be pushed back (U.S. Department of Justice 2020). Many of those awaiting asylum hearings are forced to continue to wait in the border camps discussed above, without access to basic needs or medical services. Like the detention centers, the camp conditions are primed for the proliferation and rampant spread of the virus. The legality of such a closure has been questioned by immigrant rights groups and legal experts (Guttentag 2020). The one avenue to protection that remains open is through the Convention Against Torture (CAT) (Miroff 2020), a form of relief for which the barriers to attainment are higher than those of asylum but with fewer the protections granted (American Immigration Council 2020a). Limitations of CAT that are allowed through asylum status include the inability to apply for a green card, to bring family members to the United States, and ever leave U.S. soil without losing their CAT status (American Immigration Council 2020a). Between March 21 and the beginning of May 2020, 59 screening interviews were conducted by USCIS, 54 applicants were rejected, and three cases were pending. Only two people had been granted CAT protections (Miroff 2020).

Although it is under the auspices of a public health emergency that the United States has temporarily stopped processes for the issuing of green cards and asylum claims, limited access to immigration courts, prevented the placement of children with "foster families", and turned away hundreds of unaccompanied minors at the border, ICE Air, the transportation arm of Immigration and Customs Enforcement (ICE) responsible for arranging transportation and deportation of immigrants by air, is part of the precoronavirus system that has continued to function with efficiency since March. These deportations are pulling individuals from detention facilities where, as discussed previously, both physical structures and COVID-19 cohorting policies provide a perfect storm for rapid spread of the disease, and the scope of disease incidence is not well known due to limited testing. Thus far, one out of every two people who have been tested had positive results, though as of this writing that accounts for less than $5.7 \%$ of detainees (ICE, 2020). Since President Trump declared COVID-19 a national 
emergency on March 13, 2020 (United States Government 2020), a good deal of evidence exists to suggest that the United States, the epicenter for coronavirus, is actively exporting the disease, particularly to Central America and the Caribbean.

While statistics on the number of detainees who have been deported through ICE Air since the U.S. declaration of a national emergency are not publicly available, an analysis conducted by the Center for Economic Policy and Research determined that between March 15th and April 24th, ICE Air made 71 flights, collectively, to Guatemala, Honduras, El Salvador, Brazil, Nicaragua, Ecuador, Haiti, and the Dominican Republic (Johnston 2020). As of April 17, 2020, the ICE screening process for detainees boarding ICE Air flights consisted of a temperature check in the flight line. Those with a fever above 99 degrees are removed for medical evaluation (U.S. Immigration and Customs Enforcement 2020). According to an ICE spokesperson, they lack capacity to administer tests to all passengers on ICE Air flights. Prioritizing who gets tested depends on "evolving operational considerations" (Montoya-Galvez 2020e).

Deportees to Haiti, Mexico, Jamaica, Guatemala, and Columbia have all tested positive for the virus upon arrival in their home countries (Mohammed et al. 2020). Twenty-percent of Guatemala's COVID-19 cases have been traced directly to the COVID-positive status of returned detainees (Montoya-Galvez 2020e). Haiti, already on the edge of famine, has only 62 ventilators for a population of over 11 million people (Sieff and Miroff 2020). Its capacity for quarantine exists within four hotels with 111 beds. Since April, all 111 have been designated to migrants returned on ICE deportation flights (Charles 2020). In recognition of this, the governments of both Guatemala and Haiti have repeatedly asked the U.S. to temporarily cease ICE Air flights (Charles and Madan 2020; O’Toole and Carcamo 2020b). Guatemala has gone so far as to stop deportations from the U.S. three times, first on March 17th, by suspending all incoming flights in order to create the space and time for both their government and the U.S. government to establish health protocols to help them address the COVID-19 deportation crisis (McDonnell et al. 2020; Madan and Charles 2020). As of late April, the U.S. began testing immigrants prior to deportation (Narea 2020); but, as noted above, the testing is in no way comprehensive. The danger COVID-19 poses to health systems in countries with already vulnerable public health infrastructure is both direct and potentially catastrophic. It will overwhelm marginal economic systems, further exacerbating living conditions that demand of many that they must migrate in order to survive.

\section{Conclusion}

The issues examined here confirm three realities for the U.S. immigration system. First, despite a stated moratorium on ICE enforcement (i.e., police) actions issued in March, agents continue to conduct immigration raids, set up checkpoints, and make arrests. While ICE cautioned that it would continue to take action against undocumented immigrants that pose a public safety risk, the criminal records of many of those targeted are hardly what one might expect to justify police raids during a pandemic (e.g., drunk driving, drug possession). There are also reports of ICE detaining other immigrants along with the original targets of the raids including family members or associates that are simply nearby. These anecdotes, coupled with a distrust of ICE more generally, has 
reportedly led to widespread fear that these continued enforcement actions may prevent the sick from seeking medical treatment if they are undocumented.

Evidence to date also indicates that ICE detention facilities are likely shrouded COVID-19 hotspots. Insofar as detention facilities generally are unable to adhere to CDC guidelines and testing is limited and sporadic, it is improbable that these locations can effectively detect and control the virus when it is present. Indeed, a litany of legal actions have been undertaken to remedy some of the most obvious problems and facilities in the ICE detention system, though the agency generally has been slow to respond to these directives. Moreover, there is evidence that instead of releasing detainees, many are simply shuffled around to other facilities with more space available; in some cases, such as in South Florida, these receiving facilities have already experienced a COVID outbreak.

Finally, data gathered to date indicate that deportations have continued during the pandemic and the asylum system has been, in effect, dismantled by the administration's response. These deportations are concerning for at least two main reasons; first, that the U.S. continues to violate its own, and international, law regarding asylum claims; second, that U.S. policy is contributing to the spread of coronavirus throughout Latin America and the Caribbean. As noted above, deportees to Haiti, Mexico, Jamaica, Guatemala, and Columbia have already tested positive for the virus upon arrival in their home countries (Mohammed et al. 2020) and 23\% of Guatemala's coronavirus cases have been traced directly to the COVID-positive status of returned detainees (MontoyaGalvez 2020e). As additional data are gathered, there are sure to be further cases linked to the U.S. immigration system.

Though the production and acquisition of empirical data related to COVID-19 and the immigration system are in its infancy, this paper sought to highlight how COVID19 global pandemic has changed our current understanding of the relationships between immigration policy and justice in the U.S. It is also important to note that we are only in the initial stages and logically the beginning of even understanding or hypothesizing how COVID-19 will impact U.S. immigration policy and justice as well as how other nations attempt to grapple with the complexities of immigration and justice during a pandemic. The emerging reports, arguments, and conceptualizations of U.S. immigration and justice discussed here only highlights the important advances to be made towards better understanding the correlates, contexts, and interactions of U.S. immigration policy and justice during a global pandemic. We encourage future research to further expand our evidence-based understanding of how COVID-19 has impacted U.S. immigration policies and practices, particularly in regard to the pursuit of justice. But, more importantly, it is vital to utilize evidence-based research to pursue just U.S. immigration policies and practices in this COVID-19 era.

\section{References}

Acevedo, N. (2020, May 2). "Violent clash over coronavirus tests at ICE detention center in Massachusetts, 3 sent to hospital." NBC News. Retrieved from: https://www.nbcnews.com/ news/us-news/violent-clashover-coronavirus-tests-ice-detention-center-massachusetts-3-n1198726.

Ackerman, A. R., \& Furman, R. (2013). The criminalization of immigration and the privatization of the immigration detention: Implications for justice. Contemporary Justice Review, 16(2), 251-263. 
American Civil Liberties Union. (2020a). "Immigrant rights groups sue ICE to release Maryland detainees Most at risk of COVID-19.” Press Release, March 24. https:/www.aclu.org/press-releases/immigrantrights-groups-sue-ice-release-maryland-detainees-most-risk-covid-19.

American Civil Liberties Union. (2020b). "ACLU of Texas files lawsuit against ICE to release medically vulnerable people from Texas detention facility.” Press Release, April 8. https://www.aclu.org/pressreleases/aclu-texas-files-lawsuit-against-ice-release-medically-vulnerable-people-texas.

ACLU Massachusetts. (2020). "ACLU sues ICE to release Massachusetts detainees at risk of COVID-19." Press Release, March 25. https://www.aclum.org/en/news/aclu-sues-ice-release-massachusetts-detaineesrisk-covid-19.

ACLU Pennsylvania. (2020). "ACLU urges Federal Court to release people in Immigration detention who are vulnerable to coronavirus." Press Release, March 24. https://www.aclupa.org/en/press-releases/acluurges-federal-court-release-people-immigration-detention-who-are-vulnerable.

American Immigration Council. (2020a). Policies affecting asylum seekers at the border. Washington D.C.: American Immigration Council. Retrieved from https:/www.americanimmigrationcouncil. org/research/policies-affecting-asylum-seekers-border

American Immigration Council. (2020b). A guide to children arriving at the border: Laws, policies and responses. Washington D.C.: American Immigration Council. Retrieved from: https://www. americanimmigrationcouncil.org/research/guide-children-arriving-border-laws-policies-and-responses

Associated Press. (2020, May 20). US extends heightened Enforcement during coronavirus. Retrieved from: https://www.voanews.com/usa/immigration/us-extends-heightened-border-enforcement-duringcoronavirus

Brennan Center for Justice. (2020). Courts' responses to the Covid-19 crisis. Retrieved from: https://www. brennancenter.org/our-work/research-reports/courts-responses-covid-19-crisis

Brown, M. (2020, April 17). 'This virus kills way too many people.' Hunger-striking ICE detainees demand answers." The American Prospect. https://prospect.org/justice/hunger-striking-ice-detainees-demandcoronavirus-answers/

Burness, A., \& Hindi, S. (2020, March 17). ICE immigration arrests continuing in Denver despite coronavirus outbreak. Denver Post. Retrieved from: https://www.denverpost.com/2020/03/17/coronavirus-iceimmigration-arrest-colorado-denver/

Carmody, S. (2020, April 27). ACLU files class action lawsuit to press for release of ICE detainees. NPR: Michigan Radio. Retrieved from: https://www.michiganradio.org/post/aclu-files-class-action-lawsuitpress-release-ice-detainees.

Castillo, A. (2020, April 19). Advocates say hundreds of immigrants detained in California are on hunger strike. ICE says only two." Los Angeles Times. Retrieved from: https://www.latimes.com/ california/story/2020-04-19/advocates-say-hundreds-of-immigrants-detained-in-california-are-on-hungerstrike-ice-says-just-two-are.

Centers for Disease Control. (2020). COVID-19 in Correctional and Detention Facilities - United States, February - April 2020. Retrieved from: https://www.cdc.gov/mmwr/volumes/69/wr/mm6919e1.htm

Chacón, J. M. (2010). Border exceptionalism in the era of moving borders. The Fordham Urban Law Journal, $38(1), 129-154$.

Charles, J. (2020, May 11). ICE removes detainees with coronavirus from deportation flight to Haiti. Miami Herald. Retrieved from: https://www.miamiherald.com/news/local/immigration/article242645496.html

Charles, J., and Madan, M. (2020, May 10). Haiti coronavirus panel demands that ICE halt deportations until pandemic is controlled. Miami Herald. Retrieved from: https://www.miamiherald. com/news/local/immigration/article242637741.html

Cheatham, A. (2020, February 10). U.S. detention of child migrants. Council on Foreign Relations. Retrieved from: https:/www.cfr.org/backgrounder/us-detention-child-migrants

Coleman, J. (2020, March 16). ACLU sues ICE, calls for some migrants to be released from Washington detention amid coronavirus crisis. The hill. Retrieved from: https://thehill.com/policy/nationalsecurity/department-of-homeland-security/487894-aclu-sues-ice-calling-for-some.

Democracy Now! (2020, April 22). Immigrant prisoners in Arizona must sign liability waiver to receive face masks. Democracy Now! Retrieved from: https://www.democracynow.org/2020/4/22 /headlines/immigrant_prisoners_in_arizona_must_sign_liability_waiver_to_receive_face_masks

Devereaux, R. (2020, March 27). How ICE operations in New York set the stage for a coronavirus nightmare in local jails. The Intercept. Retrieved from: https://theintercept.com/2020/03/27/immigrants-coronavirusice-detention-new-york/

Eagly, I.V., and Shafer, S. (2015). A national study of access to counsel in immigration court. University of Pennsylvania Law Review, pp.1-91. 
Frederick, J. (2019, June 29). 'Metering' at the border. National Public Radio. Retrieved from: https://www. npr.org/2019/06/29/737268856/metering-at-the-border

García Hernández, C.C. (2013). Creating crimmigration. BYU Law Review, p.1457.

Glass, I., O’Toole, M., \& Green, E. (2019, November 15). The out crowd. This American Life. Retrieved from: https://www.thisamericanlife.org/688/the-out-crowd

Gomez, A., Clark, M., \& Plavin, R. (2020, April 8). 'Terrified of dying': Immigrants beg to be released from immigration detention as coronavirus spreads." USA Today. Retrieved from: https:/www.usatoday. com/story/news/nation/2020/04/07/covid-19-hits-ice-detention-migrants-say-they-cant-clean-staysafe/2953170001/.

Guttentag, L. (2020, April 13). Coronavirus border expulsions: CDC's assault on asylum seekers and unaccompanied minors. Just security. Retrieved from: https://www.justsecurity.org/69640/coronavirusborder-expulsions-cdcs-assault-on-asylum-seekers-and-unaccompanied-minors/).

Guttentag, L., \& Bertozzi, S. M. (2020, May 11). Trump is using the pandemic to flout immigration laws." New York Times. Retrieved from: https:/www.nytimes.com/2020/05/11/opinion/trump-coronavirusimmigration.html

Hancock, L. (2020, April 25). ACLU sues ICE to release detainees from morrow, Butler County jails due to coronavirus. Cleveland.com. Retrieved from: https:/www.cleveland.com/court-justice/2020/04/aclusues-ice-to-release-detainees-from-morrow-butler-county-jails-due-to-coronavirus.html

Hernández, A. R., \& Miroff, N. (2020, April 3). Facing coronavirus pandemic, Trump suspends immigration laws and showcases vision for locked-down border. Washington Post. Retrieved from: https:/www. washingtonpost.com/national/coronavirus-trump-immigration-border/2020/04/03/23cb025a-74f9-11eaae50-7148009252e3_story.html

Hernández, D., Eason, J. M., Goldsmith, P. R., Abel, R. D., \& McNeely, A. (2018). With mass deportation comes mass punishment. Routledge Handbook on Immigration and Crime, 260-69.

Homeland Security Act of 2002. 6 U.S. Code $\S 279$.

Immigration and Nationality Act. 1952. 8 US Code $\S 1158$.

Joffe-Block, J., \& Fernández, V. (2020a, April 16). ICE tactics to limit spread of COVID-19 in detention centers stir controversy. Arizona center for investigative reporting. Retrieved from: https://azcir. org/news/2020/04/16/ice-cohorting-immigrant-detention

Joffe-Block, J., \& Fernández, V. (2020b, April 16). "La Palma cases increase after ICE assured judge of no suspected cases.” Arizona center for investigative reporting. Retrieved from: https://azcir.org/news/2020 /04/16/arizona-detention-cases-increase/

Johns Hopkins University. (2020). Asymptomatic spread makes COVID-19 tough to contain. Baltimore, MD: Author. Retrieved from: https://hub.jhu.edu/2020/05/12/gigi-gronvall-asymptomatic-spread-covid-19immunity-passports/.

Johnston, J. (2020). Exporting COVID-19: ICE air conducted deportation flights to 11 LAC, flight data shows. Center for Economic Policy and Research. Retrieved from: https://www.cepr.net/exporting-covid19-ice-air-conducted-deportation-flights-to-11-lac-countries-flight-data-shows/

Kopetman, R. (2020, April 23). Federal judge orders California ICE detention center to release detainees to ensure social distancing amid coronavirus. The Mercury News. Retrieved from: https://www. mercurynews.com/2020/04/23/federal-judge-orders-adelanto-ice-detention-center-to-release-detaineesensure-social-distancing-amid-coronavirus/

Kruzel, J. (2020, April 28). Judge rejects request to suspend immigration court hearings amid coronavirus outbreak. The Hill. Retrieved from: https://thehill.com/regulation/court-battles/495002-judge-rejectsrequest-to-suspend-immigration-court-hearings

Lanard, N. (2020, March 13). The right and wrong lessons to take from that viral photo of an ICE arrest at a hospital. Mother Jones. Retrieved from: https:/www.motherjones.com/politics/2020/03/the-right-andwrong-lessons-to-take-from-that-viral-photo-of-an-ice-arrest-at-a-hospital/

Lippa, N. (2020, April 9). Detainees at Batavia ICE facility say they are sick and haven't been tested for COVID-19. WXXI news. Retrieved from: https://www.wxxinews.org/post/detainees-batavia-ice-facilitysay-they-are-sick-and-havent-been-tested-covid-19.

Long, C. (2018). Code red: The fatal consequences of dangerously substandard medical care in immigration detention. Human Rights Watch.

Los Angeles Times. (2020). With masks at the ready, ICE agents make arrests on first day of California coronavirus lockdown. Los Angeles Times. Retrieved from: https:/www.latimes.com/gallery/withmasks-at-the-ready-ice-agents-make-arrests-on-first-day-of-california-coronavirus-lockdown

Lu, D., \& Watkins, D. (2019, January 24). Court backlog may prove bigger barrier for migrants than any wall. New York Times. Retrieved from: https:/www.nytimes.com/interactive/2019/01/24/us/migrants-borderimmigration-court.html). 
Madan, M. O. (2020a, March 26). Quarantines at Florida immigration detention centers rise as ICE arrests more migrants. Miami Herald. Retrieved from: https://www.miamiherald. com/news/local/immigration/article241504916.html

Madan, M. O. (2020b, April 30). Federal Judge Orders ICE to Release Detainees from South Florida Detention Centers. Miami Herald. Retrieved from: https://www.miamiherald. com/news/local/immigration/article242399751.html

Madan, M. O., \& Charles, J. (2020, April 23). ICE may start testing deportees pending results of coronavirus checks by CDC in Guatemala. Miami Herald. Retrieved from: https://www.miamiherald. com/news/local/immigration/article242234111.html

McDonnell, P. J., O’Toole, M., \& Carcamo, C. (2020, April 14). Guatemala health chief says at least half of deportees from U.S. have coronavirus. Los Angeles Times. Retrieved from: https://www.latimes. com/world-nation/story/2020-04-14/guatemala-health-chief-says-at-least-50-of-all-deportees-from-u-spositive-for-coronavirus

Menjívar C., Gómez Cervantes, A., \& Alvord, D. (2018). The expansion of 'Crimmigration,' mass detention, and deportation. Sociology Compass, 12(4).

Merchant, N. (2020, May 22). Judge demands ICE better explain why it won't release kids. ABC News. Retrieved from: https:/abcnews.go.com/Politics/wireStory/judge-demands-ice-explain-release-kids70845534

Meyer, J., Franco-Paredes, C., Parmer, P., \& Yasin, F. (2020, April 15). COVID-19 and the coming epidemic in the US immigration detention centers. The Lancet. Retrieved from: https://www.thelancet. com/journals/laninf/article/PIIS1473-3099(20)30295-4/fulltext.

Miller, H. V., \& Peguero, A. A. (2018). Routledge handbook on immigration and crime. New York: Routledge.

Miroff, N. (2020, May 13). Under trump border rules, U.S. has granted refuge to just two people since late march, records show. Washington Post. Retrieved from: https://www.washingtonpost. com/immigration/border-refuge-trump-records/2020/05/13/93ea9ed6-951c-11ea-8107-acde2f7a8d6e_ story.html

Mohammed, A., Cobb, J. S., \& Daniel, F. J. (2020, April 29). Two dozen people deported to Colombia on U.S. flight found to have coronavirus: Sources. Reuters. Retrieved from: https://www.reuters. com/article/us-health-coronavirus-usa-colombia/two-dozen-people-deported-to-colombia-on-u-s-flightfound-to-have-coronavirus-sources-idUSKBN22B3DB

Montoya-Galvez, C. (2020a, May 7). 20,000 migrants have been expelled along the border under coronavirus directive. CBS news. Retrieved from: https://www.cbsnews.com/news/coronavirus-20000-migrantsexpelled-border-cdc-order/

Montoya-Galvez, C. (2020b, March 30). Citing coronavirus, the U.S. is swiftly deporting unaccompanied migrant children. CBS News. Retrieved from: https:/www.cbsnews.com/news/coronavirus-us-swiftlydeporting-unaccompanied-migrant-children-citing-covid-19/

Montoya-Galvez, C. (2020c, March 31). Courts order ICE to free some immigrants, but lawmakers call for more action amid pandemic. CBS news. Retrieved from: https://www.cbsnews.com/news/coronavirusice-releases-immigrants-lawmakers-federal-courts/?ftag=CNM-00-10aab8d\&linkId=85547438

Montoya-Galvez, C. (2020d, April 3). 'Don't let us die': Women in ICE custody plead for release amid coronavirus pandemic. CBS news. Retrieved from: https://www.cbsnews.com/news/coronavirus-womenice-custody-louisiana-release-covid-19/.

Montoya-Galvez, C. (2020e, April 27). 'Exporting the virus': Migrants deported by U.S. make up $20 \%$ of Guatemala's coronavirus cases. CBS News. Retrieved from: https://www.cbsnews.com/news/deportedmigrants-guatemala-coronavirus-cases/

Montoya-Galvez, C. (2020f, April 20). Judge orders ICE to consider releasing all immigrants at risk of dying if infected by coronavirus." CBS news. Retrieved from: https:/www.cbsnews.com/news/judge-ordersice-to-consider-releasing-all-immigrants-at-risk-of-dying-if-infect-by-the-coronavirus-2020-04-20/

Montoya-Galvez, C. (2020g, May 7). U.S. suspends protections for migrant kids at border, expelling hundreds amid pandemic. CBS News. Retrieved from: https://www.cbsnews.com/news/coronavirus-immigrationmigrant-children-protections-border/).

Morrissey, K. (2020). "ACLU sues for release of ICE detainees at Otay Mesa detention center as COVID-19 cases at facility increase.” The San Diego Union-Tribune, April. 6. https://www.sandiegouniontribune. $\mathrm{com} /$ news/immigration/story/2020-04-06/aclu-sues-for-release-of-ice-detainees-at-otay-mesa-detentioncenter-as-covid-19-cases-at-facility-increase.

Mukherjee, E. (2020, February 11). Op-Ed: Here's what happens to the asylum seekers we turn away." Los Angeles Times. Retrieved from: https:/www.latimes.com/opinion/story/2020-02-11/asylum-immigrantsmexico-trump-immigration-law). 
Narea, N. (2020, May 12). Trump is continuing deportations during the pandemic. It's causing the coronavirus to spread. Vox. Retrieved from: https://www.vox.com/2020/5/12/21250540/coronavirus-immigrationlimits-trump-deportations-guatemala-honduras).

National Center for Immunization and Respiratory Disease (NCIRD), Division of Viral Diseases. (2020). Interim guidance on management of coronavirus disease 2019 (COVD-19) in correctional and detention facilities. Retrieved from: https://www.cdc.gov/coronavirus/2019-ncov/community/correctiondetention/guidance-correctional-detention.html.

New York Lawyers for the Public Interest (NYLPI). (2020). New report finds worsening crisis of inadequate medical care in immigration detention and immediate COVID-19 threat. Retrieved from: https://nylpi. org/new-report-finds-worsening-crisis-of-inadequate-medical-care-in-immigration-detention-andimmediate-covid-19-threat

O'Toole, M., \& Carcamo, C. (2020a, April 16). After dozens of deportees are positive for coronavirus, U.S. deploys CDC to Guatemala to 'validate' its tests. Los Angeles Times. Retrieved from: https://www. latimes.com/world-nation/story/2020-04-16/coronavirus-cdc-guatemala-deportees

O’Toole, M., \& Carcamo, C. (2020b, May 14). Minors' rights suffer in pandemic; U.S. is deporting migrant kids rather than releasing them to sponsors. Los Angeles Times. Retrieved from: http:/enewspaper. latimes.com/infinity/article_share.aspx?guid=a5756e7b-d81e-4443-826f-25e 55d215e75

Ornelas, I. J., Yamanis, T. J., \& Ruiz, R. A. (2020). The health of undocumented Latinx immigrants: What we know and future directions. Annual Review of Public Health, 41, 289-308.

Perrett, C. (2020, May 2). ICE arrests in Los Angeles fell drastically in one month amid the agency's focus on 'public safety' during COVID-19. Business insider. Retrieved from: https://www.businessinsider. com/ice-less-than-half-of-the-arrests-in-april-2020-5

Plevin, R. (2020, April 19). Immigrants in California detention centers launch hunger strikes to call for COVID-19 protections, advocates say." Desert sun. Retrieved from: https://www.desertsun. com/story/news/health/2020/04/19/immigrants-california-detention-centers-launch-hunger-strikes-callcovid-19-protections-advocates-sa/5162354002/

Proctor, J. (2020, May 13). Inmates: Waivers required to receive masks, a lot of unrest inside private Cibola County lockup." New Mexico in depth. Retrieved from: http://nmindepth.com/2020/05/13/inmateswaivers-required-to-receive-masks-a-lot-of-unrest-inside-private-cibola-county-lockup/.

Trevizo, P. (2020, May 11). COVID-19 cases at one Texas immigration center soared in a matter of days. Now, town leaders want answers. ProPublica. Retrieved from: https:/www.propublica.org/article/covid19-cases-at-one-texas-immigration-detention-center-soared-in-a-matter-of-days-now-town-leaders-wantanswers.

Ricciardelli, L., Nackerud, L., Cochrane, K., Crawford, L., \& Taylor, D. (2019). A snapshot of immigration court at Stewart detention center. Critical Social Work, 20(1), 46-65.

Rivlin-Nadler, M. (2020, May 7). First death of detainee in an ICE detention center from COVID-19. NPR. Retrieved from: https://www.npr.org/sections/coronavirus-live-updates/2020/05/07/ 852475822/firstdeath-of-detainee-in-an-ICE-detention-center-from-covid-19.

Sidahmed, M. (2020, April 9). ICE arrests teenager at shelter despite pandemic, places him in solitary confinement. Documented. Retrieved from: https://documentedny.com/2020/04/09/ice-arrests-teenagerat-shelter-despite-pandemic-places-him-in-solitary-confinement/

Sieff, K., \& Miroff, N. (2020, April 21). U.S. is deporting infected migrants back to vulnerable countries. Washington Post. Retrieved from: https:/www.washingtonpost.com/world/the_americas/us-is-deportinginfected-migrants-back-to-vulnerable-countries/2020/04/21/5ec3dcfe-8351-11 ea-81a3-9690c9881111 story.html

Srikrishnan, M. (2020, May 26). Border patrol activity in rural north county alarms farmworkers, advocates. Voice of San Diego. Retrieved from: https:/www.voiceofsandiego.org/topics/government/immigrationenforcement-efforts-in-rural-north-county-alarm-farmworkers-advocates/

Stracqualursi, V., Sands, G., Elkin, E., \& Rocha, V. (2019, August 23). What is the Flores settlement that the trump administration has moved to end? CNN. Retrieved from: https://www.cnn.com/2019/08/21 /politics/what-is-flores-settlement/index.html

Southern Poverty Law Center (SPLC). (2020). 'Many will die': Federal filing demands release of immigrants confined to deadly Florida detention centers. Retrieved from: https://www.splcenter. org/presscenter/many-will-die-federal-filing-demands-release-immigrants-confined-deadly-florida.

U.S. Department of Justice. (2020). EOIR operational status during coronavirus epidemic. Washington, D.C.: Executive Office for Immigration Review. Retrieved from: https:/www.justice.gov/eoir/eoir-operationalstatus-during-coronavirus-pandemic).

U.S. Immigration and Customs Enforcement. 2020. ICE Guidance on COVID-19. Retrieved May 11, 2020 (https://www.ice.gov/coronavirus). 
United States Government. (2020). Proclamation on declaring a National Emergency Concerning the novel coronavirus disease (COVID-19) outbreak. Washington, D.C.: Office of the President.

United States Senator for California, Dianne Feinstein. (2020). "Feinstein, Udall, Colleagues Call for Review of ICE Coronavirus Practices in Detention." Press Release, April 28. Retrieved from: https://www. feinstein.senate.gov/public/index.cfm/press-releases?ID=0D2A4774-21C4-493F-AECB-2644F0D570F6.

Van Fossen, E. (2020, February 10). MPP has created a refugee camp in Mexico- why aren't we treating it like one? Niskanen center. Retrieved from: https:/www.niskanencenter.org/mpp-has-created-a-refugeecamp-in-mexico-why-arent-we-treating-it-like-one/

Van Hook, J., \& Glick, J. E. (2020). Spanning borders, cultures, and generations: A decade of research on immigrant families. Journal of Marriage and Family, 82(1), 224-243.

Warikoo, N. (2020, February 12). ICE arrests 75 people in Michigan and Ohio in 1 week. Detroit Free Press. Retrieved from: https://www.freep.com/story/news/local/michigan/2020/02/12/ice-arrests-michiganohio/4737511002/

Wu, N. (2018, October 18.) What is the Flores agreement, and what happens if the trump administration withdraws from it?" Just Security. Retrieved from: https://www.justsecurity.org/61144/flores-agreementtrump-administration-withdraws-it/).

Zarrugh, A. (2020). The development of US regimes of disappearance: The war on terror, mass incarceration, and immigrant deportation. Critical Sociology, 46(2), 257-271.

Publisher's Note Springer Nature remains neutral with regard to jurisdictional claims in published maps and institutional affiliations.

Holly Ventura Miller is Professor and Graduate Program Director in the Department of Criminology and Criminal Justice at the University of North Florida in Jacksonville. Her research interests include immigration and crime, drug treatment in the criminal justice system, and program evaluation. She is a NIJ W.E.B. DuBois Fellow, Past President of the Southern Criminal Justice Association, and Vice-Chair of the ACJS Drug and Alcohol Research section.

Melissa Ripepi is currently pursuing a Ph.D. in Sociology at Virginia Tech where she is a graduate research associate for the Laboratory for the Study of Youth Inequality and Justice. Prior to that, she earned her B.A. from Virginia Tech's College of Architecture in Urban Affairs and Planning with a concentration in public policy and international studies. Her research interests include race, ethnicity, and immigration; structural violence and inequality; public policy; and education.

Amy M. Ernstes is a doctoral student in the Department of Sociology at Virginia Tech and a lecturer in the Department of Sociology at the University of North Carolina at Greensboro (UNCG). Her research interests include social inequalities, race and racism, pedagogy, and Black feminism. She is also the assistant managing editor for the Sociology of Race and Ethnicity and a graduate research associate for the Laboratory for the Study of Youth Inequality and Justice (YIJ). She received her Bachelor of Science in Social Work and Master of Social Work from Loyola University Chicago and Master of Arts in Sociology from UNCG.

Anthony A. Peguero is a Professor of Sociology and Criminology at Virginia Tech. His research interests include youth violence, socialization and marginalization, schools, and the adaptation of the children of immigrants. Dr. Peguero is also the Director of the Laboratory for the Study of Youth Inequality and Justice (YIJ) and research affiliate of the Center for Peace Studies and Violence Prevention (CPSVP). He is a member of the Racial Democracy, Crime, and Justice Network (RDCJN) and the Latina/o/x Criminology (LC) working group which hold the goals of advancing research on the intersection of race/ethnicity, crime, and justice. 